

\section{Reading London in Wartime}

Reading London in Wartime: Blitz, the People and Propaganda in 1940s Literature presents an expansive variety of writers and genres, including non-fiction and film approaches, to build a comprehensive social picture of the atmosphere during wartime London. From blitz and austerity to the nagging insistency of propaganda, this volume examines the representation of London in wartime and early post-war literature through each writer's unique perspective on the pressures of 1940s city life.

Exploring the use of London imagery, this book considers how literature redirects attention to individual, subjective experience at a time of enforced co-operation, uniformity and community. Unlike government information films and news broadcasts, which often used London to prop up prevailing clichés and stereotypes, and encouraged patriotic support for the war, literature had the freedom to express more recalcitrant truths. London writing of the 1940s was not a literature of opposition or dissent, but in offering more nuanced depictions of the period, it was a counterweight to propaganda and the general war temperament. In writing, the city becomes a more complex place, no longer the easy symbol of defiance and stoicism, of the shared sacrifice of ration book and war work. Among writers included in this study are Elizabeth Bowen, Henry Green, Patrick Hamilton, Rose Macaulay, Louis MacNeice, George Orwell and William Sansom.

William Cederwell completed his Ph.D. in English Literature at University College London in 2013. The thesis, which examines wartime London writing, forms the basis of this book. His undergraduate degree, a first-class MA Honours in English Literature, was awarded by the University of Edinburgh in 1994. He has spent several years working in a variety of roles in the media and publishing industry. 


\section{Routledge Studies in Twentieth-Century Literature}

For a full list of titles in this series, please visit www.routledge.com.

35 James Joyce, Science, and Modernist Print Culture "The Einstein of English Fiction" Jeffrey $S$. Drouin

36 British Spy Fiction and the End of Empire Sam Goodman

37 Jorge Luis Borges, Post-Analytic Philosophy, and Representation Silvia G. Dapia

38 Silent Film and U.S. Naturalist Literature

Time, Narrative, and Modernity

Katherine Fusco

39 Situationist International in Britain

Modernism, Surrealism, and the Avant-Garde

Sam Cooper

40 Surreal Beckett

Samuel Beckett and Surrealism

Alan Friedman

41 Modernism and Latin America

Transnational Networks of Literary Exchange

Patricia Novillo-Corvalan

42 New Perspectives on Community and the Modernist Subject

Finite, Singular, Exposed

Gerardo Rodríguez-Salas, Paula Martín-Salván

and María J. López

43 Reading London in Wartime

Blitz, the People and Propaganda in 1940s Literature

William Cederwell 


\section{Reading London in Wartime Blitz, the People and Propaganda in 1940s Literature}

\section{William Cederwell}

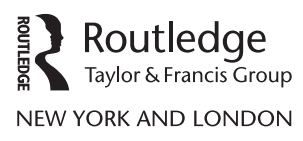


First published 2018

by Routledge

711 Third Avenue, New York, NY 10017

and by Routledge

2 Park Square, Milton Park, Abingdon, Oxon OX14 4RN

Routledge is an imprint of the Taylor \& Francis Group, an informa business

(C) 2018 Taylor \& Francis

The right of William Cederwell to be identified as author of this work has been asserted by him in accordance with sections 77 and 78 of the Copyright, Designs and Patents Act 1988.

All rights reserved. No part of this book may be reprinted or reproduced or utilised in any form or by any electronic, mechanical, or other means, now known or hereafter invented, including photocopying and recording, or in any information storage or retrieval system, without permission in writing from the publishers.

Trademark notice: Product or corporate names may be trademarks or registered trademarks, and are used only for identification and explanation without intent to infringe.

Library of Congress Cataloging in Publication Data

CIP data has been applied for.

ISBN: 978-0-8153-7578-4 (hbk)

ISBN: 978-1-351-23906-6 (ebk)

Typeset in Sabon

by codeMantra 


\section{Contents}

Acknowledgements vii

Prologue ix

Introduction 1

1 Sleeping Through the Phoney War 17

2 London Can Take It $\quad 47$

3 Affliction and Sanctuary $\quad 78$

4 In It Together? 108

5 The Literary Scene 138

6 Uneasy Peace 168

$\begin{array}{ll}\text { Conclusion } & 199\end{array}$

Bibliography 203

Index 215 
This page intentionally left blank 


\section{Acknowledgements}

This book would not have been possible without the advice and encouragement of Gregory Dart at University College London. Thanks are also due to Philip Horne and Peter Swaab at UCL, and to Michelle Salyga and the editorial and production team at Routledge.

The author gratefully acknowledges permission to use quotations from the following poems: to Stephen Stuart-Smith and the Enitharmon Press for 'Demos in Oxford Street' by David Gascoyne and 'Autumnal' by Christopher Lee; to Persephone Books for 'VJ Day' by Virginia Graham; to David Higham Associates on behalf of Faber and Faber for 'Autumn Journal', 'The British Museum Reading Room' and 'Brother Fire' by Louis MacNeice; to Marcus Watney for 'London Memory' by Antoinette Pratt-Barlow; to The Literary Estate of Kathleen Raine, copyright 2000, for 'Heroes' and 'London Revisited'; to David Dickinson for 'The Artist's Vision' by Sheila Shannon; to Susan Wanklyn, William Wanklyn and Ginny Wilson for 'Addison Road, Kensington' and 'May 8 1945: VE Day' by Patience Wheatley.

Every effort has been made to trace copyright ownership where appropriate and obtain permission; if any mistake or omission has inadvertently been made, full apologies are hereby extended. 
This page intentionally left blank 


\section{Prologue}

Walls might go, roofs might go, the prized possessions of a lifetime might be burned or broken up, but something within the people's hearts grew stronger through the harsh and noisy hours. The feeling upon which all homes throughout the world should surely be founded, stirred some of them for the first time in their isolated lives - and grew greater in those who already felt it. They felt that those who shared their danger with them - were their brothers. ${ }^{1}$

Such are the feelings of collective steadfastness in the Docklands shelter in Phyllis Bottome's blitz-set novel London Pride (1941). For these Londoners, who sing 'Home, Sweet Home' as the bombs fall, the blitz is the catalyst for new or renewed feelings of loyalty to neighbour and nation. Instead of fear or dissonance, a sense of dutiful self-sacrifice prevails, as evidenced by the unsentimental farewell to homes and possessions, precious markers of individuality and identity that are now at risk. The overriding message is of brotherly togetherness in the face of common suffering. Isolation is cast aside. War prompts the surrender of selfhood to the group.

Bottome's novel, a wartime best-seller, offers the gamut of London blitz clichés: kindly policemen; happy children evacuated to Cornwall; an Air Raid Precautions (ARP) man like a 'helmeted angel'; a munificent government quick to reimburse cockney blitz victims for destroyed furniture ('you wouldn't believe 'ow the Govern-mint's paid up ter 'elp us!'); a glorious vision of St Paul's amid ruins; nascent feelings of religious faith. There is even a hint of reformed socialist radicalism, when one docker, though still wary of 'blood-gorged capitalists', concedes that in war, 'you've got ter stand by them - Left or Right'. It is a sentiment that suits the novel's final evocation of Westminster as a symbol of fairness, of benevolent hierarchy and order, with its 'palaces of freedom, the halls of kindly kings, the abbey of a merciful God', ${ }^{2}$ all of which will survive unbeaten, despite the Nazi bombs.

Phyllis Bottome was a prolific and successful novelist, author of a biography of the Austrian psychiatrist Alfred Adler, and a writer whose work 
had transferred to the big screen; 1940 saw the release of the Hollywood film version of her novel The Mortal Storm (1937), in which James Stewart starred as a decent German holding out against the spread of Nazism in his home town. In still neutral America, the film had considerable propaganda value - a fact not lost on Bottome. In 1940, she had been in contact with the British government's propaganda department at the Ministry of Information, offering her services as lecturer or broadcaster while visiting the USA, to help reinforce the message that America's policy of isolationism should end. For Bottome, this was not unfamiliar ground. Her propaganda skills had been honed initially during the Great War, when she worked under John Buchan at the newly formed Department of Information in London.

London Pride veers strongly into propaganda territory. It certainly belongs to that body of wartime writing, filmmaking and reportage that put London at the centre of unambiguous, flag-waving depictions of Britain in the 1940s. It was an interpretation of the home-front readily absorbed at the time and that still informs how the period is remembered, particularly at times of crisis. Londoners were strong and united. They lacked self-pity. They got on with their lives, their sense of humour and determination undimmed. When death comes in London Pride, it is dealt with briskly and practically: one Docklands girl, Emily, loses her parents in the blitz, but any grief is swept aside when she is adopted by her neighbours - 'a nicer family than her own, with distinctly better prospects. ${ }^{3}$ The novel doesn't linger over the harsher facts of wartime life. The idea is encouraged instead that London quickly got back on its feet to resume the collective fight. London Pride's popularity shows that this was a message the public wanted, and needed, to hear. On the whole, home-front conditions were borne with stoicism and fortitude, and support for the war effort didn't crumble. Those clichés about wartime feeling and behaviour might have been simplistic and lacking in nuance, but they were also built on truth.

In a great deal of other home-front writing, however - in novels and short stories, in poems and diaries - a more uncomfortable reality emerges. Cracks in morale become clear as people struggle to live up to the popular image of the hardy Londoner 'taking it', as the cheery slogans put it. A less idealised city comes to the fore: despondent and under pressure, bound by wartime controls and regulations, burdened by sacrifices, exhaustion and loss. The Second World War did not see a literature of opposition or dissent take root in Britain. Writers were keen to do their bit. In the main, they were not anti-war. They were also aware that literature was not the same as propaganda. A line had to be drawn between what they did and what the propagandists did. Literature needed to be divorced from government meddling, was the repeated message. It needed to be divorced, too, from politics. Writers should have no agenda. They were not Ministry of Information hirelings, 
writing stirring war-themed novels and poems to order. The world of the imagination was to remain free.

As London Pride illustrates, that dividing line was often tenuous. Neither was the intention of the author always clear. Graham Greene's short story 'The Lieutenant Died Last' (1940), in which a heroic English village fights off an advance party of German parachutists, was first published in the American magazine Collier's. A more overt propagandistic film adaptation from Ealing Studios, Went the Day Well?, followed in 1942. Although Greene was working at the Ministry of Information in 1940, he denied that the story was written at the ministry's behest. Another stirring home-front (albeit American-made) film from 1942, Mrs Miniver, was also adapted from a literary work: Jan Struther's 1939 book about a middle-class London family. A success in America, it won over readers to the plight of a plucky Britain, fighting alone. Effective as it was as propaganda, however, Struther's book was simply a collection of her popular 'Mrs Miniver' columns from The Times, most of which predated the war and were intended as a light-hearted diversion on the paper's court pages. Literature could have considerable propaganda value, intended or not. Even more negative or downcast writing could be said to fulfil a propaganda role; freedom to publish revealed that Britain was still an open, liberal country standing firm against repressive totalitarianism.

The aim of this study is to explore what 1940 s writing brings to our understanding of wartime London and, more broadly, to the home-front. The city was central to the glorified vision of Britain. In news reports and radio broadcasts, it was eulogised and celebrated. It shaped the nation's mood. The accent in propaganda was firmly on the group, the people. In the closing scenes of the Ministry of Information film London Can Take It! (1940), the American journalist narrator Quentin Reynolds (his sonorous voice a world away from the ordinary Londoner's), declaims that while the blitz might destroy buildings and destroy lives, it 'cannot kill the unconquerable spirit and courage of the people of London'. What matters here is the valiant civilian army. The trials of war were to be borne together - and as London did, so the rest of the country would follow. In responding with ambivalence and irony, with uncertainty, literature was preoccupied less with this ordered, regimented, tin-hatted citizenry than with its antithesis: the often doubting, anxious, solitary Londoner, at odds with the atmosphere of collective effort and resilience. This is not always the case, as London Pride makes clear, but in the works of Elizabeth Bowen, Henry Green, Inez Holden, Rose Macaulay, Louis MacNeice, William Sansom and Evelyn Waugh, to name a few, literature tests and questions. It brings a working out of experience, with meaning found in interiority and specificity rather than generalities. Here too is an illustration of the power of literature, in a far wider sense. In giving dramatic and poetic shape to life, it is uniquely 
placed to explore the human condition, to give play to the sorts of intricacies and complexities unconsidered elsewhere.

After an analysis in the introduction of the themes in 1940s London writing, the following chapters will look at the city's pre-war mood, the truth about London 'taking it', the health of its people, its communal bonds, and the significance of London's literary magazines. The final chapter centres on London in the tough years of peace (1951, the year of the Festival of Britain, provides an appropriate end date). The range of primary sources is broad. Contemporary writing is favoured, partly because of the rich seam of untapped material, and partly because of the greater immediacy that such works provide. More canonical literature is included alongside lesser-known works. Films and diaries have also been referenced. Despite this breadth, the spotlight remains on the city, charting how writing wrestled with the image of London as the site of blitz-generated myth.

\section{Notes}

1 Bottome, London Pride (Faber \& Faber, 1941), p. 109.

2 Bottome, p. 69; p. 74; p. 55; p. 135; pp. 107-8; p. 67; p. 207.

3 Bottome, p. 150.

4 London Can Take It!, Humphrey Jennings and Harry Watt (1940). 


\section{Introduction}

\section{London as Icon}

'The smoke parted like the curtain of a theatre and there before me was this wonderful vista, more like a dream', Herbert Mason, a Daily Mail photographer recalled. In the sudden moment of clearer sky, 'the shining cross, dome and towers stood out like a symbol in the inferno. The scene was unbelievable'. The vision was of St Paul's Cathedral, miraculously still standing, after the air raid of 29 December 1940 - a night so bad it became known as the Second Fire of London. Mason's photograph appeared on the newspaper's front page on 31 December, providing the type of striking iconography of the home-front that London did so well. In addition to St Paul's, one thinks of Tube shelters, searchlights and barrage balloons, firemen battling City flames, office workers picking their way through smashed masonry on the morning commute, the King and Queen touring the East End and VE day crowds in Piccadilly Circus.

Across Britain, other towns and cities suffered devastating blitzes: southern ports, industrial centres in England, Wales, Scotland and Northern Ireland, picturesque tourist spots targeted in the Baedeker raids. The quieter countryside wasn't immune. The first civilian death, in March 1940, six months before the London blitz began, was not in the East End docks; it was a villager from Bridge of Waithe in the Orkneys, killed when the nearby naval base at Scapa Flow was bombed. However, outside London, blitzed Britain generated fewer narratives, provided fewer memorable images and offered fewer opportunities to boost morale. The dome of St Paul's could be co-opted into the wartime propaganda machine in a way that Coventry's burnt-out cathedral could not. Coventry gave rise to a gloomy and frightening new word, 'coventration', while St Paul's became an easier symbol of indomitableness. Hull, said to have been Britain's second-most bombed city, was typical in how overshadowed other regions were by London in shaping the way Britain saw itself, and is still remembered, during the 1939-45 war. 


\section{Introduction}

In providing so much striking imagery, London was the source of myth, of the idealisation of the nation. When Humphrey Jennings filmed Londoners calmly queueing for shelters, working as ambulance drivers and air-raid wardens, sweeping up after a night of bombing, it was a dignified illustration for the rest of Britain, and the world, in how to 'carry on'. Scenes such as this come from Jennings's and Harry Watt's London Can Take It! (1940), a nine-minute documentary made principally to impress cinema audiences in America with the phlegm and sangfroid of the British under attack. Produced for the Ministry of Information by the GPO Film Unit, it captured with understated power life in the wartime capital. With minor changes and a new title, Britain Can Take It! (1940), it was subsequently released for domestic distribution. London was setting the standard in how to cope; a fact reinforced by a shot of St Paul's in the opening scenes and later views of other landmarks, Trafalgar Square and the Houses of Parliament.

As a model of wartime behaviour, London, above all, was heroic. The city had been bombed before. In the Great War, Zeppelin raids saw Londoners shelter in the Underground, providing the artist Walter Bayes with the subject for his five-and-half metre long painting The Underworld: Taking Cover in a Tube Station during a London Air Raid (1918), in which patient figures wait at Elephant and Castle for the danger to pass. But the beginning of the blitz in 1940 dwarfed anything that had gone before. London truly was on the front line now, and would be, sporadically, until 1945, with the cycles of bombing culminating in the V1 and V2 attacks in the last two years of war. In 1914-18, trenches in muddy French fields were named after London streets: Petticoat Lane, Regent Street, Hyde Park Corner. Now, in that first, most intense stage of bombing, from September 1940 to May 1941, London no longer had to be imagined as a place of everyday death and bombardment. The trenches had come home, to London's parks and communal gardens.

In addition to their bravery, Londoners were united and they were strong. The waiting beds in the four neurological hospitals set up around London to cope with the predicted rush of blitz-induced breakdowns were not for them. ${ }^{2}$ Neither would Londoners descend into petty squabbles and infighting. Here was a real citizenry, no longer divided by class or wealth. Such was the impression of London in wartime: uncomplaining and determined, willing to put up with hardship, and with a clear idea of what the fight was about. All ambivalence was kept at bay. If London's wartime experience was so exalted, if it was turned into a message and a moral, then it is also true that it took on an insisting, almost coercive character. The expectation to behave and think in a certain way, to present a certain front, can be seen as one of the many exhortations and instructions that pervaded everyday life. As war made its steady encroachments, home-front Britons faced a creeping subjugation. It wasn't 
just a matter of black-out and bombing, of rationing and war work, of the insistent wail of siren and all-clear. A host of new rules and defence regulations was transforming the nation. Constitutional changes suspended habeas corpus, allowed the government to tap phones and open mail, made it a criminal offence to spread defeatism (the 'no naughty talk' order, as one diarist put it). ${ }^{3}$ People were told what they could eat, wear, say, where they could work and live and travel; they were urged not to gossip and to dig for victory. In Patrick Hamilton's The Slaves of Solitude (1947), the commute into wartime London is to experience the 'lecturing and admonitions', the 'nagging', on every billboard, hoarding and newspaper kiosk, the journey becoming 'a sort of gauntlet of "No's" and "Don'ts". 4 As Ian McLaine, in his history of the Ministry of Information argued, the public was "bombarded with innumerable appeals and instructions [...] There was scarcely an aspect of the individual's life on which the state did not have something to say'. None of this was unique to London, and yet it was London's experience, above anywhere else, that was turned into an exemplary narrative, an often-repeated story worming its way into the popular imagination. It was a conscription of consciousness.

The elevation of wartime London was not a lie. It wasn't a Ministry of Information ruse to fortify a nervous population. As the Union Jacks that appeared in the rubble of London houses showed, patriotic feeling was strong. Adapting to the stereotype of the stoical Londoner, or adopting the positive rhetoric of the blitz, was also good for morale. It helped people to cope and forged consensus. It provided meaning and reassurance. In bleaker moments - the harsh winter of 1940-1, or the depressing months of 1944, when the V1 campaign began - it was also a necessary survival tactic. ${ }^{6}$ There was a need, even a desire, for uplifting imagery and optimistic propaganda. People wanted direction, to be shown that the war was necessary and just, that hardships were shared, that victory was possible. ${ }^{7}$ Nevertheless, the 'London can take it' mantra was so pervasive, and so enduring, that it threatened to eclipse alternative points of view, to mould all opinion and debate.

Dissenting voices in wartime were free to criticise. The writer and journalist Ritchie Calder was frank in his depiction of working-class suffering. ${ }^{8}$ Parts of blitzed East and South London, he wrote, were as bad as Great War battlefields: this was Ypres, or Delville Wood, or Hill 60, transplanted to London's humdrum streets. ${ }^{9}$ Vera Brittain, the pacifist and peace campaigner, felt the same. A five-hour tour of bombed London reminded her of the time she had driven with Winifred Holtby through the ruined villages of the Somme in $1921 .{ }^{10}$ As shocking were the unsanitary and poorly equipped rest centres, put up to provide temporary care and respite for bombed-out Londoners. In one notorious incident, to which Calder referred, hundreds of blitz survivors in Canning Town, abandoned at their rest centre when buses got lost on the way 


\section{Introduction}

to evacuate them, were killed in a second wave of bombing. ${ }^{11}$ And yet Calder, who later worked as a propagandist for the Foreign Office's Political Warfare Executive, ${ }^{12}$ was also a firm believer in London's glorified war experience. The blitz, in his eyes, was nothing less than 'the greatest spectacle of mass-heroism in history'. ${ }^{13}$

It would take time - about thirty years, in the opinion of the historian Angus Calder (Ritchie Calder's son) ${ }^{14}$ - for a more realistic, sceptical appraisal of the wartime period. Writing his account of the blitz in 1976, Tom Harrisson, co-founder (along with Humphrey Jennings and the poet Charles Madge) of Mass-Observation, called time on all 'the exaggerations' and 'propaganda of heroism', most of which was directed at the London cockney. ${ }^{15}$ In the early 1990s, Angus Calder and Clive Ponting were among those historians to explore how the war's iconic moments - the blitz, Dunkirk, the Battle of Britain - depended on a careful and selective editing. (Their arguments hark back to Roland Barthes' work on modern, cultural myths. ${ }^{16}$ As Calder wrote, such moments were 'instantaneously and spontaneously "mythologised", acquiring an 'aura of absoluteness, uniqueness, definitiveness'. This aura was built on truth and real experience, but only partially so, with a sieving out of anything that didn't quite fit. No matter that pacifist feeling was more widespread than commonly believed, or that certain trade unionists and intellectuals in Scotland and Wales might lose faith in 'a failing British cause', ${ }^{17}$ or that Bomber Command, following a February 1942 directive to aim for built-up areas, ${ }^{18}$ was inflicting on German civilians far greater devastation than was being visited on British cities. Certain facts needed to be overlooked if the emphasis was to remain on British unity, courage and moral authority. For Ponting, the celebration of Britain's 'bulldog spirit' depended on forgetting such unwelcome truths, not least that Churchill was not universally liked, or that the government at one stage considered negotiating peace with Hitler. Malta, Gibraltar, Britain's African colonies and the Falkland Islands were said to have been up for discussion. ${ }^{19}$

Not everyone agreed with Calder or Ponting. While it did no good to glorify Britain's 1939-45 record, the historian Arthur Marwick argued, neither was it right 'to deny the exaltation, the sense of achievement and the heightening of consciousness'. ${ }^{20}$ For others, a deflating revisionism was now prioritising negativities and social antagonism in wartime Britain. ${ }^{21}$ But however convinced, or not, by home-front myths, what is clear is that London became a lasting symbol of Britain's finest hour. Taking its lead from St Paul's, the rest of London, and the nation, was emerging through the smoke and finding itself transformed. Looking back more than twenty-five years after the war, Elizabeth Bowen was still encouraged by this positive 'collective image' of the wartime city - a place where she had lived and worked and 
loved; it 'was inspirational; one beheld oneself as one had it in one to be. The image was a winner'. ${ }^{22}$

\section{The Home-Front Writer}

Writers in wartime didn't set out to be oppositional. They weren't taking their cue from the poet and literary critic Herbert Read, who argued in Poetry and Anarchism (1938) that the poet should be 'the agent of destruction in society'; it was better to go to prison 'than submit to the indignities of war and collectivism', he wrote. ${ }^{23}$ Almost all writers supported the war and the war effort. If not on active service, they worked as air-raid wardens and firewatchers, or they produced propaganda for the Ministry of Information and the BBC. Elizabeth Bowen carried out secret war work, compiling a report on Irish neutrality for the government. George Orwell, despite being so clear about the hopelessness of war after Spain, would have happily died for his country in the fight against Nazism, he wrote in his diary. To his great disappointment, poor health kept him a civilian. He was classed as a C- case, which meant no armed service wanted him. ${ }^{24}$ On the whole, writers didn't distance themselves from the conflict. Some may have ignored the war as best they could, spending their evenings getting drunk in Fitzrovia, but they veered more towards the activism and patriotism of J.B. Priestley than the boozy disengagement of Julian Maclaren-Ross.

If not all London-set writing of the 1940s set out to challenge, to cut through the gauze of glory and heroic deeds, then neither was all of it interesting or illuminating. One early piece of wartime literary criticism, in the influential cultural review Horizon in 1941, offered a scathing analysis of the initial crop of war-themed novels. Most were escapist, low brow, forgettable. 'Never have I felt that I owed so little to so many', quipped the reviewer, Mass-Observation's Tom Harrisson. It was a judgement not only about novels with an RAF theme, but about contemporary fiction more generally, including the blitz-set pieces. The novels were superficial, with unconvincing heroes and sensational touches, Harrisson argued. The intellectual was usually depicted as suspect, a pacifist poet-type trying to upset the decencies of home-front life. ${ }^{25}$ War was not the spur to a great literary or poetic flourishing, as it had been a generation earlier. Where were the Sassoons and Wilfred Owens, the Rupert Brookes, commentators asked?

More recent opinion, echoing Harrisson, has singled out the weakness of 1940s writing. Angus Calder, whose seminal studies of the period include The People's War (1969) and The Myth of the Blitz (1991), thought that few writers and artists were able to 'step outside conventional discourses' and capture war's true intensities. One of Calder's exceptions was the painter Francis Bacon, particularly the sense of grotesque horror 


\section{Introduction}

and anguish in Three Studies for Figures at the Base of a Crucifixion from 1944. The literary critic Paul Fussell, best known for his research on the Great War, argued that 1940s literature lacked irony and scepticism, with Priestley a typical example of this tendency towards wartime sanctimoniousness and cant. Other critics and historians say that the 1940s have been dismissed as a barren period for English fiction, with no major works, or argue that wartime propaganda, endorsed and absorbed by an obedient, patriotic population, was simply too strong a force for most literature and art to resist. Others have made the point that not all wartime writing set about exposing truths and unravelling myths. Waxing lyrical about urban ruins in the moonlight or the rosy skies over blitzed cities could camouflage death and suffering. ${ }^{26}$

But the best and most interesting, the richest London-set writing from the period - the novels of Nigel Balchin and Henry Green; the short stories of Bowen, Anna Kavan and William Sansom; and the poetry of Louis MacNeice, not to mention a host of aspiring and amateur writers does stand up to such criticism. Instead of rehashing the same platitudes and truisms, meaningful insight is brought to home-front life. Here is the fullness of experience, the conflicting eddies and currents of feeling. Cheerful optimism was not inauthentic. There are moments of stirring heroism and sentiment, of great pride and sacrifice - but there is also an awareness and avoidance of cliché. Responses to war were complex and multi-layered. The bombing of London was frequently conveyed as a sublime experience. The blitz was terror mixed with excitement. With death and destruction came the thrill of the moment; the beauty of the fire-lit night sky was in that same instant bringing annihilation. And yet even this could be turned into cliché. To concentrate on the febrile, frantic blitz months was to ignore the more general boredom of the home front, the long, dull years of privation and crushing greyness.

While there has been a tendency to see particular value in the more experimental literature of the 1940s, the writing of the home-front was a broad church. It resists convenient labels or assimilation into one overarching school. Modernist innovation in the stories of Green or Sansom existed alongside the elegant satire of Mollie Panter-Downes and Evelyn Waugh. Elizabeth Bowen hovered between realism and a more haunted, fragile sensibility. Nigel Balchin captured home-front life with a pared-down prose, seemingly free of lyricism. James Hanley's work was more impressionistic, while Inez Holden's writing was praised for its documentary style. Graham Greene's The Ministry of Fear (1943), a fast-paced thriller involving fifth columnists, was also a telling comment about wartime identity. In poetry, the so-called new-Romantic movement - noted for its abstraction and opacity - flourished, while other poets, such as Dylan Thomas and Edith Sitwell, were praised for a new naturalness and simplicity. This diversity is reflected in literary criticism; for all those who see a natural link between war writing and 
modernism, there are others who argue that realism best lent itself to the strangeness of home-front life. ${ }^{27}$

However they wrote, and whatever they wrote, writers generally remained free from government interference. There was much debate at the time about how far Britain, in fighting totalitarianism, was adopting totalitarian methods of its own. When the Emergency Powers (Defence) Act was passed in May 1940, giving Westminster unprecedented powers - including the right to requisition property, to determine pay and tax profits, to direct employment - the London-based American journalist Ed Murrow was aghast. It was a revolution, he broadcast to the USA: the British government now controlled 'all persons, rich or poor, employer or worker, man or woman, and all property. All of it - including the land'; although drastically different from her enemies, 'Britain now becomes a totalitarian state'. ${ }^{28}$ Given these worries, expressed throughout the war, about a gathering atmosphere of home-grown autocracy, it was to the government's benefit if it left writers alone. Voices of dissent were evidence of the country's commitment to free speech. London in this respect was never going to be like Berlin or Rome, or allied Moscow. In wartime, the people were reminded of this: a travelling exhibition was held on the home-front, contrasting British and Nazi attitudes to books. One of its stops was at Charing Cross station, as if to remind book-reading commuters that London was a city in which literature, like them, was free. ${ }^{29}$ The fact that writers weren't bullied by the state was grist to Britain's wartime propaganda mill.

The government's hands-off policy regarding literature extended to newspaper editorial opinion. At times, the government did lose patience with the direction of certain newspapers and magazines, including the Daily Mail and Picture Post, while the Communist Party newspaper the Daily Worker and Claud Cockburn's controversial left-wing news sheet The Week faced lengthy suspensions in 1941. (Several non-fiction titles from Penguin, on India and postwar reconstruction, also met with disapproval.) ${ }^{30}$ The censors were concerned chiefly with hard news, in order not to let slip details of military and tactical importance. Filmmakers and artists, meanwhile, were more susceptible to interference from officialdom. Painters had to get permission before they set up their easels in city streets. They were also deterred by the War Artists' Advisory Committee at the Ministry of Information from painting inappropriate scenes of panic, grief or alarm, such as people coming under attack. No bodies were depicted. (Instead it was destroyed buildings that came to symbolise human suffering). ${ }^{31}$ Wartime cinema faced its own restrictions. All films had to be officially endorsed, in some form. Permits were needed for film stock, and projects usually required Ministry of Information approval and a British Board of Film Censors certificate. Although Powell and Pressburger's comedy The Life and Death of Colonel Blimp (1943) ruffled a few feathers, upsetting Churchill with its 


\section{Introduction}

portrayal of outmoded military thinking, nothing could be made without the government's seal of approval. The ministry's close - and often low-key - influence over film production, including commercial films and documentaries, was matched by the careful monitoring of all newsreel footage. The BBC, meanwhile, was also under ministry supervision and toed an uncontroversial line. ${ }^{32}$

When it came to fiction and poetry, official scrutiny was mostly absent. Orwell's Animal Farm (1945) was the notable exception. T.S. Eliot at Faber and Victor Gollancz were among those publishers who turned it down, while an initially receptive Jonathan Cape was said to have been put off by a Ministry of Information official's warning that the antiSoviet allegory might give offence to allied Russia. Secker \& Warburg eventually published the novel once the war was over, in August 1945, with its anti-Stalinist message intact. On the whole, it is debatable whether literature, however potentially divisive or controversial, ever really concerned the government. Books were more likely to be suppressed on grounds of obscenity than anti-war sentiment. Two of the best-known banned novels in the 1940s continued to be D.H. Lawrence's Lady Chatterley's Lover and Radclyffe Hall's The Well of Loneliness, both of which had first appeared in print in 1928. If wartime fiction caused a stir, it was usually on similar grounds of propriety. John Lehmann, at the Hogarth Press, faced just this problem with Henry Green's novel Caught (1943), set in a London fire station. When the printers objected to its colourful language, Green was forced to make suitable amends, while Lehmann wrote an apology to the head of the printing firm. ${ }^{33}$ Here was the more typical example of wartime meddling in fiction. Swearing, not sedition, was the issue - and it was the printer, not a shadowy ministry official, who complained.

Fiction's limited reach was another reason why it didn't trouble the government unduly. On the one hand, with so many entertainments curtailed, there was an eager audience for anything in print, and publishers battled to meet demand in the face of paper rationing and air-raid damage to printing works and stores. National expenditure on books increased from $£ 9$ million in 1939 to $£ 23$ million in $1945,{ }^{34}$ and the city's literary magazines, such as Horizon and Penguin New Writing, tapped into this voracious appetite for reading and writing. Yet the number of new novels published fell by over half during the course of the war. ${ }^{35}$ Although there was an increase in poetry writing, ${ }^{36}$ published in magazines and anthologies, many new writers found it hard to get into print and, as the author Mollie Panter-Downes noted, few new works were available. ${ }^{37}$ The real bestsellers of wartime tended to be government illustrated books, technical and educational titles on engineering, or practical wartime help, or battlefronts, as C. Day Lewis explained. ${ }^{38}$ According to The Bookseller in 1942, fiction comprised a mere $10 \%$ of that year's published books; ${ }^{39}$ the biggest share, $45 \%$, was technical, 
medical and educational - and it is just these sorts of publications that most involved the Ministry of Information. The ministry's book division, at one stage headed by Graham Greene, focused on non-fiction publications, including magazines and pamphlets, particularly if these were to be sent overseas. Health Hints for Factory Workers was a typical title the ministry hoped to see to fruition. 'What We Are Fighting For' was an article intended for Picture Post. ${ }^{40}$

The ministry often had dealings with writers, but this was mostly to secure their co-operation in such ventures (for instance, asking Julian Huxley, Dorothy L. Sayers and Hugh Walpole to contribute to an unnamed Macmillan series), ${ }^{41}$ rather than directing the course of their literary work. At other times, it suggested non-fiction topics to publishers, who then found and commissioned the authors. One such proposal, a commercial success, was 'Britain in Pictures', a series of slim volumes published by Collins between 1941 and 1950 that celebrated the nation's character, customs and traditions. ${ }^{42}$ John Betjeman, Graham Greene, Rose Macaulay, George Orwell and Virginia Woolf were among the high-profile contributors. Convincing publishing houses to engage in these projects was not difficult, rewarded as they were with an increase in their paper supply. ${ }^{43}$ It was this control over paper, rather than a heavyhanded approach to censorship, that was at the heart of the ministry's wartime influence over the publishing industry. ${ }^{44}$ As with newspapers, censorship tended to focus on details of potential tactical advantage to the enemy.

Of the fiction that was being read, new novels about war weren't always a popular choice. Among the most borrowed library books in 1942 were Margaret Mitchell's Gone With the Wind (1936); Rachel Field's All This, and Heaven Too (1938), a true-crime drama set in nineteenth-century France; How Green was my Valley (1939), Richard Llewellyn's nostalgic look at a Welsh mining community; and Daphne du Maurier's Rebecca (1938). Eric Knight's This Above All (1941) was one of the few frequently borrowed titles with a contemporary war setting, about lovers across the class divide. All these books had been turned into Hollywood feature films in the 1940s, which partly explains their popularity. Other in demand titles included the Everyman's Library reprints of classics, the works of Jane Austen, Dickens and Thackeray, while Tolstoy's War and Peace was recommended by E.M. Forster in a BBC radio talk. ${ }^{45}$ (This was a reversal of a prewar trend noted by Orwell; in 1936 he remarked on the lack of appetite for Austen, Dickens, Thackeray and Trollope. The same was true of shortstory collections - another literary form that would do well in wartime. ${ }^{46}$ Given this combination of non-fiction bestsellers and reprints, and the lack of fresh material, it was no wonder that the publishing scene seemed so moribund to some. ${ }^{47}$ Nothing important was being published, reckoned Ed Murrow. Intellectual life counted for little; men who could fly planes and build ships were needed - not the men who could 'write and talk'. ${ }^{48}$ 


\section{0}

London writing of the 1940s didn't worry the blue-pencilled censors. In Harrisson's opinion, it was also of limited merit. But at its best it offered a fuller, more individualised picture of home-front London. It was literature that addressed the questions overlooked in propaganda and poster campaigns, in newsreels and BBC broadcasts. Without it, our understanding of the period would be incomplete.

\section{The Individual in the City Street}

Despite their professed distaste for propaganda, home-front writers were instrumental in its production. Orwell, who argued in 'Inside the Whale' (1940) that literature needed to be free of politics and government interference, produced radio talks to the colonies on literary matters - just the type of soft propaganda that formed the mainstay of the BBC's overseas output. The poet Louis MacNeice, who wrote that he loathed propaganda, ${ }^{49}$ was also at the BBC, working on scripts for broadcasts to America, among other tasks. (London was an inspiration: MacNeice's BBC series The Stones Cry Out featured London's blitz-damaged landmarks.) E.M. Forster, meanwhile, maintained that the artist needed to be an outsider, noting with caution the tendency, thanks to the BBC and Ministry of Information, to 'draw him out and treat him as a particularly bright public servant'; it inhibited the 'creative impulse', he argued. ${ }^{50}$ Nevertheless, Forster also wrote for the $\mathrm{BBC}$ in wartime and gave radio talks. Forster's comments here come from a speech at the annual congress of the literary society PEN (Poets, Essayists, Novelists), in September 1941. (In a symbolic gesture, London was chosen as that year's host city; the meeting was held at the Institut Français in South Kensington.) The contrast between literature and propaganda was a theme some of the PEN speakers tackled. Propagandists dealt in half-truths and surrendered their freedom in order to disseminate a doctrine, argued the novelist Phyllis Bentley, while the creative writer's 'vision of the world, is emphatically his own'. For Arthur Koestler, all art had a propaganda aspect, in what the artist or writer chose to omit or include from their work - but involvement in conscious propaganda 'means the artist's abdication'. The artist should not be a leader, in Koestler's opinion; 'his mission is not to solve but to expose; not to preach but to demonstrate'. (Both Bentley and Koestler worked closely with the Ministry of Information in wartime, Bentley with the ministry's American division.)

The PEN speeches also underlined literature's preoccupation with the individual, the inherent value seen in each 'single human being, the most obscure, the least outspoken', as Storm Jameson, PEN president, put it. For J.B. Priestley, the life the writer understood was 'the personal life, life as experienced by persons in themselves as individuals and life as known in personal relationships'. Although a believer in the nobility of 
nationalism, in her speech Rebecca West stated that novelists and poets found inspiration in the unique quality of the individual; 'any human being is worth studying, because every individual has his unique experience, his unique vision of humanity'. However universal the truths it explored, literature's building blocks were the intimate, the close-up, the detailed. As Phyllis Bentley put it, fiction could imply 'the entire cosmos' in the smallest, most personal moment, perhaps even 'the events of one hour as they are reflected in one mind, ${ }^{51}$

The PEN congress wasn't marking new ground for literature, especially when it comes to the novel, a literary form that has been associated, since its seventeenth-century origins, with individualism, with the truth of individual perception rather than the types of universal certainties inherited from the classical and medieval periods. ${ }^{52}$ But the unavoidable context in 1941, in London, in those blitzed South Kensington streets, was war and the home-front. The need was for individual voices, for questioning, uncertain, tentative points of view that might not be so bonded to the heroic, stoical collective. In a broader sense, too, it was a period in history that needed literature to perform this role; it was, as Orwell argued, a more generalised totalitarian moment, 'an epoch of fear, tyranny, and regimentation', of 'concentration-camps, rubber truncheons, Hitler, Stalin, bombs, aeroplanes'. ${ }^{53}$ The idea that writing offered a refuge for individualism, and anti-authoritarianism, became more acute. Modern literature, Orwell stated in a 1941 BBC broadcast, was 'essentially an individual thing. It is either the truthful expression of what one man thinks and feels, or it is nothing. ${ }^{54}$

Postwar anthologists and bibliographers picked up on this quality in 1940s literature. Given how wartime made such demands on selfhood and identity, the role of poetry as an honest exploration of subjectivity was heightened, argued Ronald Blythe, whose anthology of wartime writing appeared in 1966:

The great thing was not to pretend, or proffer solutions, or to be histrionic. Each poet spoke as wholly and truthfully as he could from out of the one inviolate spot of an otherwise violated order, his own identity. ${ }^{55}$

Dan Davin, compiling his anthology of wartime short stories in 1982, noted how writing in war was an assertion of individual freedom - not only from war conditions, but also from the way war turned conscripted men into 'a unit in a world of units, a member of a demanding family and of a commanding hierarchy'. Even the solitude that writing required became a symbolic act, a way 'to betray the system'. Catherine Reilly, who published an extensive bibliography of Second World War poetry, argued that the outpouring of poetry-writing in the 1940s might have included a great deal of unpolished verse, but because it dealt with 


\section{Introduction}

'personal involvement', or 'loss or longing', or 'the emotions felt during a time of action', it was generally redeemed by emotional truth: 'The incidents of war did not make the poetry; the poetry was made by the poets' honest responses.'56

Not that a compensatory emphasis on subjectivity and personalism provided an answer to the pressures of wartime life. It could make matters worse - increasing the sense of dread and isolation, of helplessness, in the face of major events. And neither did this emphasis necessarily provide a clearer dividing line between literature and propaganda. (As the first head of the Ministry of Information Lord Macmillan stated, a key theme of propaganda was the sanctity of the individual. $)^{57}$ Nevertheless, the idea that literature offered subtler ways of interpreting experience was more sharply defined when the emphasis elsewhere was on civic duty and responsibility, on the nation. As Elizabeth Bowen put it in 1945, people 'assembled and checked themselves from stories and poems', as well as memories and conversations. They sought in books 'the communicative touch of personal life, ${ }^{58}$ If the call in wartime was away from individuality and subjectivity, away from personality too - what really mattered was to be an effective unit in the war machine - then writing and reading offered a necessary breathing space. In a nation with a liberal history and a strong regard for privacy, literature provided a release from the unrelenting grasp of war, of propaganda, of the group. Literature valued the 'single human being', in Storm Jameson's words, and it needed to be free of political direction, of official meddling.

$* * *$

It is in literature that one finds the counterweight to official histories and popular imaginings of the wartime period. It allows room for contradiction and qualification. It challenges wartime rhetoric. The simple, reassuring insistencies of propaganda are brushed aside. Nothing else matched literature in this regard: Louis MacNeice's long prewar poem Autumn Journal (1939) captured the atmosphere of approaching war in London; Henry Green's wartime novel Caught (1943) showed Londoners (in this case, a team of firemen) becoming enmeshed in the exaggerations of their heroic public image; the novels of Nigel Balchin and Inez Holden made clear the frustration and boredom of war work; writers such as Elizabeth Bowen and Anna Kavan used themes of memory and identity to explore how war threatened to eclipse their protagonists.

A noticeable trait about the works considered in the following chapters is how London is used to embrace these individual doubts and hesitations. Typical is 'Alien Country', a poem by an unknown writer, Jim Hovell, who worked at the Air Ministry before serving in the army. Coming home on leave, the poet finds in London a comic rebuttal to all the stereotypes suggested to an absent soldier. His family bickers about 
food shortages, Soho pubs are dangerous, the streets seedy, friends and lovers give him short shrift.

I come and go on leave and (as they see it) am uncommitted, disinterested, uninvolved, transient, a tourist, circumspectly welcomed temporarily among them but not, now, one of them, not, now, one of the natives of the place.

The poem's lack of structure or rhyme scheme, its artlessness, suggest a loosening of ideals, mirroring the poet's disappointment that the real city is not the one he thought he would find. It is a fitting style for a London that is less a brave collective than a place of petty, selfish ordinariness. 'While the world goes up in flames', the poet finds the homefront bickering about daily trivialities, the chance of 'a bit more cheese next week'.

Clearly, the fate of western civilisation depends upon tins of Spam and packets of dried egg and draconian measures to ensure that the butchers do not reserve their offal for their fancy women.

The sense here is not of a city putting up a fight. The tone is not the certainty of propaganda, but an uncertain singularity, an isolated individual voice in a city that ostracises rather than welcomes. His difference is reinforced, as is London's, from the ideal:

I venture with trepidation into this alien country with its ambiguous landscape, obscure pre-occupations and shifting relationships. ${ }^{59}$

The following chapters will follow a path through this ambiguous landscape, charting how London from 1939 to 1951 was reimagined in writing, and what this adds to our understanding of the period, its people and its literature.

\section{Notes}

1 Fitz Gibbon, The Blitz (Allan Wingate, 1957), p. 212; Smith, Britain and 1940: History, Myth and Popular Memory (Routledge, 2000), pp. 80-1.

2 Anon., 'A Description of the Treatment Facilities for Civilian Psychoneurotic Casualties Provided by the Emergency Medical Service 1940', in Emanuel Miller (ed.), The Neuroses in War (Macmillan, 1940), p. 227.

3 Cockett, Love and War in London: A Woman's Diary 1939-1942, ed. Robert Malcolmson (Wilfrid Laurier University Press, 2005), pp. 106-7.

4 Hamilton, The Slaves of Solitude (Constable, 2006), pp. 134-5. 
5 McLaine, Ministry of Morale: Home Front Morale and the Ministry of Information in World War II (George Allen \& Unwin, 1979), p. 252.

6 Smith, p. 29.

7 Balfour, Propaganda in War 1939-1945 (Routledge \& Kegan Paul, 1979), p. 75.

8 Calder, Carry on London (English Universities Press, 1941) and The Lesson of London (Secker \& Warburg, 1941).

9 Calder, Lesson, p. 36.

10 Brittain, England's Hour: An Autobiography 1939-1941 (Futura, 1981), p. 208.

11 Calder, Lesson, p. 20.

12 In a blog post, 'Tradecraft of propaganda' (June 2010), his son, Nigel Calder, said this appointment was the government's attempt to silence Ritchie Calder's reports. www.calderup.wordpress.com/tag/political-warfare-executive.

13 Calder, Lesson, p. 62.

14 Calder, Disasters and Heroes: On War, Memory and Representation (University of Wales Press, 2004), p. 67.

15 Harrisson, Living Through the Blitz (Collins, 1976), p. 202.

16 Ponting, 1940: Myth and Reality (Hamish Hamilton, 1990). Angus Calder, The Myth of the Blitz (Jonathan Cape, 1991). A myth is not intended to mislead, Barthes wrote; it is less a lie than a distortion, 'an inflexion'. Barthes also saw myth as having 'an imperative, buttonholing character', trying to enlist the support of each individual; see 'Myth Today' in Mythologies (1957), translated by Annette Lavers (Vintage, 2000), p. 129; p. 124. Barthes' theories chime with how wartime propaganda was conceived, as Philip Taylor remarks, as a fight to gain control over the individual and 'independent thought'; see Munitions of the Mind: A History of Propaganda from the Ancient World to the Present Era (Manchester University Press, 1995), p. 1. Home-front writing, in contrast, edges closer to the type of function that A.P. Foulkes detects in literature: its ability to expose and take on propaganda, its power to produce 'a counter-vision which in turn creates the sense of ideological distance which renders propaganda visible'; see Literature and Propaganda (Methuen, 1983), p. 6.

17 Calder (1991), pp. 1-2; p. 90.

18 Lindqvist, A History of Bombing (Granta, 2001), p. 194.

19 Ponting, pp. 96-7; p. 194.

20 Marwick, The Home Front: The British and the Second World War (Thames and Hudson, 1976), p. 181.

21 Addison, 'Churchill and the Price of Victory 1939-1945', in Nick Tiratsoo (ed.), From Blitz to Blair: A New History of Britain since 1939 (Weidenfeld \& Nicholson, 1997), p. 54.

22 Bowen, review of Angus Calder's The People's War, in The Spectator, 19 September 1969 , p. 15.

23 Read, Poetry and Anarchism (Faber and Faber, 1938), p. 15; p. 17.

24 Orwell, Diaries, ed. Peter Davison (Harvill Secker, 2009), p. 264; p. 272.

25 Harrisson, 'War Books', Horizon, no. 24 (1941), p. 417.

26 Calder (1991), p. 143; p. 180. Fussell, Wartime: Understanding and Behaviour in the Second World War (Oxford University Press, 1989), p. 171; p. 179. Hewison, Under Siege: Literary Life in London 1939-1945 (Methuen, 1988) argues that the blitz inspired few good poems, p. 51. Munton, English Fiction of the Second World War (Faber and Faber, 1989) notes that wartime is deemed a lost period of English fiction, p. 20. Piette, Imagination at War: British Fiction and Poetry 1939-1945 (Papermac, 1995) argues that, 
however independent, most writers couldn't escape how war 'enervated and outclassed' private imagination, p. 2; Rawlinson, British Writing of the Second World War (Clarendon Press, 2005), writes that fiction could help sanitise war, pp. 78-80.

27 Boston, Wave Me Goodbye: Stories of the Second World War (Penguin, 1989), p. 12, argues that much wartime short fiction had the 'rawness of journalism'; 'realism was often the most appropriate medium; it suited the urgency of the time'. Greg LeStage, preface to Good Evening Mrs Craven: The Wartime Stories of Mollie Panter-Downes (Persephone, 1999), p. xi, notes that the 'reality of wartime was so comparably unreal that realism in fiction was utterly apt'. Alan Munton (1989), p. 31, singles out 1939 as the date of modernism's retreat. Esty, A Shrinking Island: Modernism and National Culture in England (Princeton University Press, 2004), and Harris, Romantic Moderns (Thames \& Hudson, 2010), argue that modernism in Britain was undergoing a significant change in this period, a retreat from abstraction and embrace of a national identity rooted in images of the country and tradition. Esty, pp. 2-3, describes it as a moment of 'cultural particularity', when London modernism, and certain aspects of modernist literary practice, started to become obsolete. Harris, p. 97, notes that modernism scorned what was craved most in wartime: solidity, comfort, reassurance. See also MacKay, Modernism and World War II (Cambridge University Press, 2007), Mellor, Reading the Ruins: Modernism, Bombsites and British Culture (Cambridge University Press, 2011) and Wasson, Urban Gothic of the Second World War: Dark London (Palgrave Macmillan, 2010): they argue that modernism, surrealism and the gothic were suited to literary depictions of the 1940s city, its blitzed atmosphere in which time, structure and characters become fragmented. Stonebridge, The Writing of Anxiety: Imagining Wartime in Mid-Century British Culture (Palgrave Macmillan, 2007) argues that gothic, melodrama and fantasy in wartime writing were used to convey trauma and anxiety. Rod Mengham, 'Broken Glass', in R. Mengham and N.H. Reeve (eds.), The Fiction of the 1940s: Stories of Survival (Palgrave, 2001), notes that wartime literature emphasised fragmentation and broken communication over completion and certainty. The consensus here is to chart the relationship between war and modernism, to see in the bomb-damaged streets the type of fracture and dislocation that earlier modernists had made a central part of their writing.

28 Murrow, This Is London (Cassell, 1941), p. 112; p. 114.

29 Holman, Print for Victory: Book Publishing in England 1939-1945 (British Library, 2008), p. 48; p. 99.

30 Lewis, Penguin Special (Viking, 2005), p. 199.

31 Ulrike Smalley, 'London at War', Gresham College lecture, 22 October 2007, www.gresham.ac.uk/lectures-and-events/london-at-war.

32 Taylor, p. 218. Reeves, The Power of Film Propaganda: Myth or Reality? (Cassell, 1999), p. 161. Aldgate and Richards, Best of British: Cinema and Society 1930-1970 (Basil Blackwell, 1983). Balfour (1979), p. 85.

33 Lehmann, Thrown to the Woolfs (Weidenfeld and Nicolson, 1978), p. 117.

34 Hewison, p. 86.

35 The number fell from 4,222 in 1939 to 1,179 in 1945; see Bergonzi, Wartime and Aftermath: English Literature and its Background 1939-1960 (Oxford University Press, 1993), p. 21.

36 Hewison, p. 111.

37 Panter-Downes, London War Notes 1939-1945, ed. William Shawn (Longman, 1972), p. 178. 


\section{Introduction}

38 Day Lewis, 'Do We Read Better Books in Wartime?', Picture Post, 25 March 1944 , p. 22.

39 Holman, p. 61.

40 London, National Archives, 'Re-organisation of the General Production Division', INF 1/86. MS dated 26-7 August, 11 October and 1 November 1940.

41 ibid.

42 The originator of the project was Hilda Matheson at the Ministry of Information.

43 McLaine, p. 48.

44 Holman, p. 248.

45 Holman, pp. 52-3; p. 262. Hewison, p. 93.

46 Orwell, 'Bookshop Memories' (1936), in John Carey (ed.), George Orwell: Essays (Everyman's Library 2002), pp. 52-3; Hewison, p. 91.

47 Hodges, Gollancz: The Story of a Publishing House 1928-1978 (Gollancz, 1978), p. 150.

48 Murrow, p. 167.

49 MacNeice, 'London Letter: Blackouts, Bureaucracy \& Courage', Common Sense (February 1941), in Alan Heuser (ed.), Selected Prose of Louis MacNeice (Clarendon Press, 1990), p. 105.

50 Forster, 'The New Disorder', in Hermon Ould (ed.), Writers in Freedom: A Symposium Based on the XVII International Congress of the PEN Club Held in London in September 1941 (Hutchinson, 1942), p. 76.

51 See Writers in Freedom, p. 15 (Jameson); p. 19 (Priestley); p. 21 (West); pp. 53-4 (Bentley); pp. 63-4 (Koestler).

52 Watt, The Rise of the Novel (Chatto \& Windus, 1957). Terry Eagleton notes that it was in the 1940s that Mikhail Bakhtin and Erich Auerbach (the former a dissident in Soviet Russia, the latter an Istanbul-based Jewish refugee from Hitler) were elaborating on the idea of the novel as 'a populist strike against autocratic power'. Bakhtin's notion was of linguistic diversity, or heteroglossia, in the novel; Auerbach's was the novel's democratic, multipersonal shifting perspectives; see The English Novel (Blackwell, 2005), pp. 7-9.

53 Orwell, 'Inside the Whale' (1940), in Carey, p. 219.

54 Orwell, 'Literature and Totalitarianism' (1941), in Carey, p. 361.

55 Blythe (ed.), Writing in a War: 3 pp. 103-4.

56 Davin (ed.), Short Stories from the Second World War (Oxford University Press, 1984), p. xii. Reilly, English Poetry of the Second World War: A Bibliography (G.K. Hall, 1986), p. xiv.

57 McLaine, p. 141.

58 Bowen, 'Postscript to The Demon Lover' (1945), in Hermione Lee (ed.), The Mulberry Tree: Writings of Elizabeth Bowen (Virago, 1986), p. 97.

59 Hovell, 'Alien Country', in Victor Selwyn (ed.), The Voice of War: Poems of the Second World War (Penguin, 1996), pp. 103-4. 


\section{References}

Original publication dates in square brackets. 